\title{
SEROLOGICAL AND MOLECULAR SURVEY OF Leptospira spp. AMONG CART HORSES FROM AN ENDEMIC AREA OF HUMAN LEPTOSPIROSIS IN CURITIBA, SOUTHERN BRAZIL
}

Mariane Angélica FINGER(1), Ivan Roque de BARROS FILHO(1), Christian LEUTENEGGER(2), Marko ESTRADA(2), Leila Sabrina ULLMANN(3), Hélio LANGONI(3), Mariana KIKUTI(3), Peterson Triches DORNBUSH(1), Ivan DECONTO(1) \& Alexander Welker BIONDO(1)

\begin{abstract}
SUMMARY
Introduction: Cart horses are a re-emerging population employed to carry recyclable material in cities. Methods: Sixty-two horses were sampled in an endemic area of human leptospirosis. The microscopic agglutination test (MAT) and real-time polymerase chain reaction (qPCR) were performed. Results: A seropositivity of $75.8 \%$ with serovar Icterohaemorrhagiae in $80.8 \%$ of the horses was observed. Blood and urine were qPCR negative. MAT showed positive correlations with rainfall $(p=0.02)$ and flooding $(p=$ 0.03). Conclusions: Although horses may be constantly exposed to Leptospira spp. in the environment mostly because of rainfall and flooding, no leptospiremia or leptospiruria were observed in this study.
\end{abstract}

KEYWORDS: Leptospira spp.; MAT; qPCR; Horses.

\section{INTRODUCTION}

Leptospirosis is a worldwide zoonosis in which rats play an important role as reservoirs maintaining the Leptospira spp. cycle in urban areas of tropical countries ${ }^{1}$. People are exposed to pathogenic Leptospira spp. from human beings, dogs, horses, and other domestic animals, since these are susceptible species and may share living areas ${ }^{4}$. Identification of factors affecting leptospiral dynamics in host populations, such as environmental transmission factors, may contribute towards intervention, control, and preventive measures relating to urban human leptospirosis and its impact on public health ${ }^{2}$.

The disease is highly endemic in Brazil, with over 10,000 human cases notified between 2009 and 2011, and an overall death rate of $9.3 \%$. The number of confirmed cases and deaths has been increasing in the state of Paraná, particularly in the city of Curitiba. The state of Paraná and the city of Curitiba had 201 and 80 confirmed cases, respectively, in 2009, with 12 deaths in the capital, 306 and 170 confirmed cases, respectively, in 2010, with 26 deaths; and 347 and 182 confirmed cases, respectively, with 31 deaths, in $2011^{13}$.

The microscopic agglutination test (MAT), which determines agglutinating antibodies in sera for various serovars of Leptospira spp., is considered to be the gold standard for leptospirosis diagnosis ${ }^{14}$. Recent molecular approaches, such as real-time polymerase chain reaction (qPCR), have been applied to detect a DNA sequence of a gene (LipL32) which is present only in pathogenic species of Leptospira spp. ${ }^{14}$.
Although leptospiral infection in horses has been associated with recurrent equine uveitis, abortions, and other systemic signals, these animals are generally asymptomatic ${ }^{12}$. Experimental infection using the Leptospira interrogans serovar Kinnenwicki in horses has demonstrated leptospiremia two to six days after infection and leptospiruria four weeks after infection, thus, indicating that horses may disseminate the disease ${ }^{16}$. Although horses may share common areas with humans and shed Leptospira spp. in urine, the role of naturally infected horses in leptospirosis transmission remains to be entirely established ${ }^{3}$.

Cart horses have recently re-emerged as urban fauna, used by the low-income population to carry recyclable material around urban centers $^{8}$. Approximately 1,500 cart horses share the urban area of Curitiba, capital of the state of Paraná and the seventh largest city in Brazil, with a population of over three million living in the metropolitan area $^{5}$. Although cart horses and their owners pass through the city limits on a daily basis, there is a lack of studies of the influence of horse populations in endemic urban areas of human leptospirosis. Accordingly, the present study aims to investigate Leptospira spp. seroprevalence, leptospiremia, and leptospiruria among cart horses in Vila Pantanal ("Swamp Village"), an urban area of Curitiba, in Southern Brazil, which is an endemic area of leptospirosis. In addition, the risk factors for leptospirosis, such as open sewers, garbage accumulation, flooding, and the presence of rodents, as well as the concurrent presence of several animal species, such as pigs, chickens, dogs, cats, horses, and goats, were evaluated by means of questionnaires applied to the respective local horse owners.

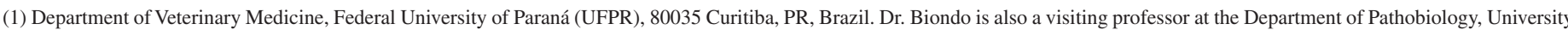
of Illinois, Urbana, IL, 61802, USA.

(2) Real Time PCR Core Facility, Idexx Reference Laboratories. 2825 Kovr Dr, West Sacramento, CA, 95605, USA.

(3) Department of Veterinary Hygiene and Public Health, Veterinary School, São Paulo State University, 18618 Botucatu, SP, Brazil.

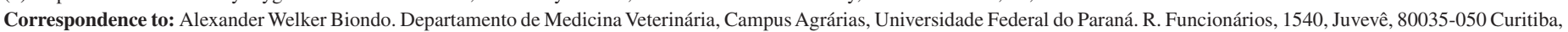
PR, Brasil. Phone: +55 413350 5723; Fax: +55 413350 5623. E-mail: abiondo@illinois.edu 


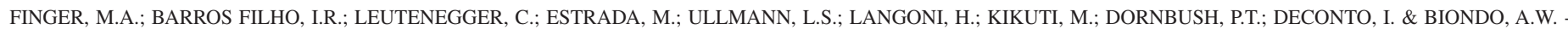
Serological and molecular survey of Leptospira spp. among cart horses from an endemic area of human leptospirosis in Curitiba, Southern Brazil. Rev. Inst. Med. Trop. Sao Paulo, 56(6): 473-6, 2014.

\section{MATERIALS AND METHODS}

Three samplings of a total of 62 cart horses used for carrying recyclable material and housed in an endemic area of human leptospirosis in Curitiba, Southern Brazil, were performed. Vila Pantanal is located in an area of irregular land occupation, within the Environmental Protection Area of Iguassu, and had poor sanitary conditions, garbage accumulation, and flooding at the time when the sampling took place ${ }^{11}$. On the first two visits (October, 2009 and May, 2010), only a serological survey was conducted. In light of the results, a third and comprehensive visit was made (November, 2010) to collect urine, blood, and serum samples. On the first and second visits, 25 and 20 serum samples were obtained, respectively. On the third visit, a total of 22 serum, urine, and blood samples were obtained. Three horses participated in two samplings and one in all three. On the third visit, horse owners were asked to complete a questionnaire developed by the World Health Organization ${ }^{15}$.

Blood samples were obtained by means of venipuncture, from which serum was obtained by centrifugation at 3,000 rpm for 10 minutes, and stored at $-20{ }^{\circ} \mathrm{C}$ until processing. Packed cell volume (PCV), total plasmatic protein (TPP), and fibrinogen were measured in capillary tubes, in a microcentrifuge and refractometer following $56^{\circ} \mathrm{C}$ incubation. Urine samples were obtained by means of urethral catheters and a syringe, after animal sedation, using intravenous acepromazine $(0.05 \mathrm{mg} / \mathrm{kg}$ body weight).

The serum samples were initially diluted at 1:50 using $100 \mu \mathrm{L}$ of serum and 4,900 $\mu \mathrm{L}$ of phosphate buffered saline (SSTF) ( $\mathrm{pH}$ 7.6). A $50-\mu \mathrm{L}$ volume of diluted serum was distributed in microplates and 50 $\mu \mathrm{L}$ of the serovar was added, thus doubling the initial dilution (1:100). The same procedure was performed for negative control samples, and the samples were tested against 11 serovars of Leptospira interrogans: Bratislava (Jez-Bratislava), Canicola (Hond Utrecht IV), Djasiman (Djasiman), Copenhageni (M20), Icterohaemorraghiae (RGA), Pomona (Pomona), Pyrogenes (Salinem), Wolffi (3705), Hardjo prajitno (Norma), Hardjo-mini (Neguita), Hardjo-CTG (local sample from the state of Minas Gerais, not internationally recognized) ${ }^{10} ; 1$ serovar of Leptospira kirshneri: Grippotyphosa (Moskva V); and three serovars of Leptospira borgpetersenii: Castellonis (Castellon 3), Hardjo-bovis (L171), and Tarassovi (Perepelicin). Titers greater than or equal to 100 were considered reactive.

Quantitative PCR was performed on 22 whole blood, urine, and serum samples, in an attempt to find leptospiral nucleic acids. DNA was extracted under standard protocols on a commercial platform (Corbett XTractor-Gene, Qiagen, Valencia, CA, USA) and a housekeeping gene (18S rRNA) was used to determine DNA content and quality. The PCR test was based on IDEXX's proprietary real-time PCR oligonucleotides (IDEXX Laboratories, Westbrook, ME, USA). Real-time PCR was performed using default cycling conditions on a commercial instrument (Roche LC480 in the 384-well plate configuration, Roche Applied Science, Indianapolis, IN, USA).

Commercially available statistical software (GraphPad V.5) was used to test associations between leptospiral infection and risk factors. Rainfall data covering the 30 days prior to each visit was obtained from a local forecasting system ${ }^{6}$. The forecast station, where the data were collected, was located around $15 \mathrm{~km}$ from where the horses were kept.

Fisher's test was used in the questionnaire and laboratory data. Linear regression was applied to the rainfall and serological data.

This study was approved by the ethics committee of the Federal University of Paraná.

\section{RESULTS AND DISCUSSION}

Antibodies against Leptospira spp. were observed in 47/62 (75.8\%) horses and antibodies against Leptospira interrogans serovar Icterohaemorrhagiae were found in $38 / 47$ (80.8\%) horses. Table 1 shows the serological survey results according to serovar. Detection of antibodies against Leptospira spp. according to the visit was observed

Table 1

Frequency of Leptospira interrogans in cart horses according to serovar, Curitiba, PR, 2013

\begin{tabular}{llll}
\hline Sampling & 01 & 02 & 03 \\
\hline Serovar & Icterohaemorrhagiae & Icterohaemorrhagiae & Icterohaemorrhagiae \\
Frequency & $64 \%(16 / 25)$ & $45 \%(9 / 20)$ & $50 \%(11 / 22)$ \\
Serovar & Canicola, Icterohaemorrhagiae & Canicola, Icterohaemorrhagiae & Icterohaemorrhagiae, Castellonis \\
Frequency & $4 \%(1 / 25)$ & $5 \%(1 / 20)$ & $13.63 \%(3 / 22)$ \\
Serovar & Bratislava & Bratislava & Icterohaemorrhagiae, Castellonis and \\
Frequency & $8 \%(2 / 25)$ & $5 \%(1 / 20)$ & Pyrogenes \\
Serovar & Canicola & Gryppotyphosa & $4.50 \%(1 / 22)$ \\
Frequency & $8 \%(2 / 25)$ & $5 \%(1 / 20)$ & \\
Serovar & Canicola, Pyrogenes, Hardjo pratijino & & \\
Frequency & $4 \%(1 / 25)$ & & \\
Serovar & Canicola, Pyrogenes & & \\
Frequency & $4 \%(1 / 25)$ & & \\
Serovar & Bratislava, Icterohaemorrhagiae & & \\
Frequency & $4 \%(1 / 25)$ & & \\
Serovar & Pomona & & \\
Frequency & $4 \%(1 / 25)$ & & \\
\hline
\end{tabular}




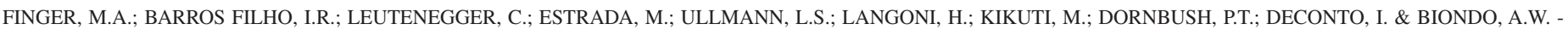

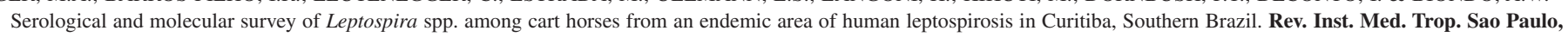
56(6): 473-6, 2014.

Table 2

Horses that have participated in more than one sampling, Curitiba, PR, 2013

\begin{tabular}{lccc}
\hline Animal & Sampling 01 & Sampling 02 & Sampling 03 \\
\hline $\mathbf{0 1}$ & 400 Icterohaemorrhagiae & 400 Icterohaemorrhagiae & Not determined \\
$\mathbf{0 2}$ & 200 Icterohaemorrhagiae & 400 Icterohaemorrhagiae & 400 Icterohaemorrhagiae \\
$\mathbf{0 3}$ & 400 Icterohaemorrhagiae & Not determined & 200 Icterohaemorrhagiae, 100 Castellonis \\
$\mathbf{0 4}$ & Not determined & 400 Icterohaemorrhagiae & 400 Icterohaemorrhagiae \\
\hline
\end{tabular}

in $25 / 25$ horses $(100 \%)$ in the first sampling, $12 / 20(60 \%)$ in the second, and $15 / 22(68.18 \%)$ in the third. No samples of whole blood or urine were found to be positive for Leptospira spp. in the molecular diagnostic test. Three animals participated in two samplings and one animal in all three. The interval between the first and second samplings was seven months; between the second and third, six months; and between the first and third, 13 months. There were variations in the titers of these three horses and none became nonreactive (Table 2).

The laboratory test averages for the reactive and nonreactive animals in the third sampling were TPP, $7.76 \pm 0.68$ and $7.77 \pm 0.62$ $\mathrm{g} / \mathrm{dL}$; fibrinogen, $473.33 \pm 237.95$ and $400 \pm 239.04 \mathrm{mg} / \mathrm{dL}$; and PCV, $39 \pm 0.07 \%$ and $37 \pm 0.08 \%$, respectively. There were no differences in the values for TPP $(p=0.28)$, fibrinogen $(p=0.09)$, or PCV $(p=0.13)$ between the reactive and nonreactive animals. The results relating to the epidemiological investigation are shown in Table 3.

Rainfall before the first, second, and third samplings was 304, 222, and $74 \mathrm{~mm}$, respectively. Comparison between the serological test results and rainfall showed a positive correlation $(p=0.03)$ : the higher the rainfall, the greater the serological test result. It is important to remember that different horses were tested in this period and the previous status of the horses was unknown. So, although they were statistically significant and with blood samples obtained with higher intervals than observed for a drop in the MAT titers in previous reports ${ }^{16}$, the MAT titers found could be a result of former infections. Therefore, one cannot rule out biased sampling and further studies should be conducted, in order to establish all the observed results and significant comparisons.

The frequency of Leptospira spp. and Leptospira interrogans serovar Icterohaemorrhagiae observed in this study can be considered high compared to those of previous studies, where L. interrogans serovar Icterohaemorrhagiae has been observed to be more frequent, including antibodies in 757/1,402 (54\%) sport and work horses in the states of São Paulo, Mato Grosso do Sul, and Goiás ${ }^{7}$, and in 82/182 (45\%) horses also in Goiás ${ }^{9}$. Prevalence of $214 / 320(66.88 \%)$ was observed in cart horses, which were studied in the urban area of Londrina, in the state of Paraná, using MAT, but without signs of leptospirosis ${ }^{3}$. The horses in this study may have been more exposed to leptospiral contact, because of the propitious environment for Leptospira spp. survival, leading to the high percentage of antibodies observed.

Among the horses that were sampled more than once, it was observed that horse number 2 presented an increase in its L. interrogans serovar Icterohaemorrhagiae titer from the first to the second sampling, and maintained this in the third. Horse number 3 showed a smaller $L$. interrogans serovar Icterohaemorrhagiae titer from the first to the third sampling (interval of 13 months), but showed a L. interrogans serovar
Table 3

Epidemiologic investigation of Leptospira spp. in 22 cart horses of Curitiba, PR, Brazil, 2013. (Statistical test: Fisher's test)

\begin{tabular}{lrrr}
\hline & \multicolumn{3}{c}{ November 2010 } \\
\cline { 2 - 4 } & Reagent & Non reagent & $p$ \\
\hline $\begin{array}{l}\text { Contact with mud, garbage and } \\
\text { sewage }\end{array}$ & & & \\
$\quad$ Yes & $9(60 \%)$ & $3(42.86 \%)$ & 0.27 \\
$\quad$ No & $6(40 \%)$ & $4(57.14 \%)$ & \\
House located less than 20 meters & & & \\
from garbage accumulation & & & \\
$\quad$ Yes & $9(60 \%)$ & $6(85.71 \%)$ & 0.20 \\
$\quad$ No & $6(40 \%)$ & $1(14.29 \%)$ & \\
House located less than 10 meters & & & \\
from open sewage & & & \\
$\quad$ Yes & $11(73.33 \%)$ & $5(71.43 \%)$ & 0.38 \\
$\quad$ No & $4(26.67 \%)$ & $2(28.57 \%)$ & \\
Presence of rodents near house & & & \\
$\quad$ Yes & $14(93.33 \%)$ & $4(57.14 \%)$ & 0.07 \\
$\quad$ No & $1(6.67 \%)$ & $3(42.86 \%)$ & \\
Flooding near house & & & 0.02 \\
$\quad$ Yes & $8(53.33 \%)$ & 0 & \\
No & $7(46.67 \%)$ & $7(100 \%)$ & \\
\hline
\end{tabular}

Castellonis titer in the third sampling, whereas it had previously been nonreactive. Animals 1 and 4 maintained their titers and serovars between samplings. It is important to highlight that these four animals had the same owner and lived in the same environment.

In a previous study, the titers of horses experimentally infected with Leptospira interrogans serovar Kinnewicki were found to appear five or six days after infection, with a peak occurring on the $14^{\text {th }}$ day, followed by a decline and finally disappearing from 40 to 60 days after infection ${ }^{16}$. The intervals between sample collections in this study were longer (six and seven months) than the 40- to 60-day period for disappearance of the titer, which shows that the horses probably remained reactive because of constant contact with leptospires in their environment. Furthermore, in the experimental infection study, leptospiruria was shown by means of dark field microscopy and culturing four weeks after infection and leptospiremia was shown by means of blood culturing between two and six days after infection. In previous studies, leptospiruria and leptospiremia were observed in animals that were infected with $10 \times$ $10^{8}$ leptospires via ocular and intraperitoneal routes; animals infected 


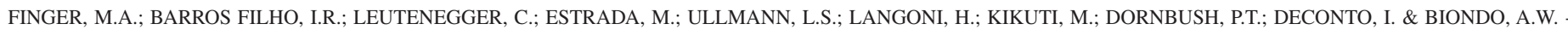
Serological and molecular survey of Leptospira spp. among cart horses from an endemic area of human leptospirosis in Curitiba, Southern Brazil. Rev. Inst. Med. Trop. Sao Paulo, 56(6): 473-6, 2014.

with $5 \times 10^{8}$ leptospires via ocular and subcutaneous routes did not present leptospiruria and leptospiremia ${ }^{16}$. The molecular diagnostic test in this study demonstrated that the horses did not have leptospiremia or leptospiruria, probably, because the sampling was not performed during an acute phase of infection. There is no data on the quantity of Leptospira spp. that could have infected the horses in the present study or in relation to the infection route; these factors could influence the occurrence of leptospiremia and leptospiruria.

Following the epidemiological investigation (Table 3), it can be assumed that flooding is a risk factor for leptospirosis infection. Animals living in urban areas where the sanitary conditions and infrastructure are poor, close to dumps, open sewers, and discarded materials, and in proximity to other animal species, constitute a population that is particularly at risk of leptospirosis ${ }^{5}$. This study was conducted in the city of Curitiba, which exhibited these characteristics and, thus, the horses studied constituted a population at risk.

The laboratory tests (PCV, TPP, and fibrinogen) were not affected by positive serological findings of Leptospira spp. in the present study. A previous experimental infection study on horses showed that animals infected with $10 \times 10^{8}$ leptospires through ocular and intraperitoneal routes presented anemia, although, the same was not observed among animals infected with $5 \times 10^{8}$ leptospires through ocular and subcutaneous routes ${ }^{16}$. It is possible that the route of infection and the quantity of infectious organisms influenced the laboratory test results and that the horses in this study had leptospires infection with no occurrence of the disease. A positive correlation between serological test findings and rainfall was also observed in a study on dogs in the same area ${ }^{11}$.

\section{CONCLUSIONS}

Although cart horses may be continuously exposed to environmental Leptospira spp., mostly because of rainfall and flooding, no leptospiremia or leptospiruria were observed in the present study by means of qPCR. Increased rainfall and flooding are risk factors for Leptospira spp. contact among horses. PCV, TPP, and fibrinogen may be unaffected by Leptospira spp. infection.

\section{RESUMO}

\section{Inquérito sorológico e molecular de Leptospira spp. em cavalos carroceiros de área endêmica para leptospirose humana em Curitiba, Sul do Brasil}

Introdução: Cavalos carroceiros são uma população reemergente empregada para transportar materiais recicláveis em cidades. Métodos: Em área endêmica para leptospirose humana foram amostrados 62 cavalos. Soroaglutinação microscópica e reação em cadeia da polimerase em tempo real foram empregadas. Resultados: Observouse soropositividade em 75,8\% com sorovar Icterohaemorrhagiae em $80,8 \%$ cavalos. Amostras de sangue e urina foram negativas no qPCR. Observou-se correlação positiva entre SAM e pluviosidade $(p=0,02)$ e alagamentos $(p=0,03)$. Conclusão: Embora cavalos possam estar constantemente expostos a Leptospira spp. no ambiente, principalmente por chuvas e inundações, leptospiremia e leptospiruria não foram encontradas neste estudo.

\section{ACKNOWLEDGMENTS}

To Curitiba Zoonosis Control Center, UFPR Cart Horse Project and Idexx Laboratories.

\section{REFERENCES}

1. Adler B, de La Peña Moctezuma A. Leptospira and leptospirosis. Vet Microbiol. 2010;140:287-96.

2. Dias JP, Teixeira MG, Costa MCN, Mendes CMC, Guimarães P, Reis MG, et al. Factors associated with Leptospira sp. infection in a large urban center in northeastern Brasil. Rev Soc Bras Med Trop. 2007;40:499-504.

3. Hashimoto VY, Gonçalves DD, Silva FG, Oliveira RC, Alves LA, Reichmann P, et al. Occurrence of antibodies against Leptospira spp. in horses of the urban area of Londrina, Paraná, Brazil. Rev Inst Med Trop Sao Paulo. 2007;49:327-30.

4. Houwers DJ, Goris MGA, Abdoel T, Kas JA, Knobbe SS,van Dongen AM, et al. Agglutinating antibodies against pathogenic Leptospira in healthy dogs and horses indicate common exposure and regular occurrence of subclinical infections. Vet Microbiol. 2011;148:449-51.

5. Instituto Brasileiro de Geografia e Estatística. Sinopse do Censo Demográfico 2010. Available from: http://www.ibge.gov.br

6. Instituto Nacional de Metereologia. [Cited 2011 Aug]. Available from: www.inmet.gov.b

7. Langoni H, Da Silva AV, Pezerico SB, De Lima VY. Anti-leptospire agglutinins in equine sera, from São Paulo, Goias and Mato Grosso do Sul, Brazil, 1996-2001. J Venom Anim Toxins incl Trop Dis. 2004;10:207-18.

8. Lara MCCS, Furman KE, Barros Filho IR, Villalobos EMC, Cunha SEM, Deconto I, et al. Detection of antibodies against equine viral arteritis virus (Evav) and equine herpesvirus type 1 (Ehv-1) in cart horses from Curitiba and surroundings, Southern Brazil. Arch Vet Sci. 2006;11:11-4.

9. Linhares GFC, Girio RJS, Linhares DCL, Mondeiros LC, Oliveira APA. Sorovares de Leptospira interrogans e respectivas prevalências em cavalos da microrregião de Goiânia, GO. Cienc Anim Bras. 2005;6:255-9.

10. Moreira EC. Avaliação de métodos para erradicação de leptospirose em bovinos leiteiros. [Tese]. Belo Horizonte: Universidade Federal de Minas Gerais, Escola de Medicina Veterinária; 1994.

11. Morikawa VM. Estudo sorológico da infecção por Leptospira spp. em uma área de ocupação irregular e de alto risco para a doença em cães em Curitiba, PR. [Dissertação]. Curitiba: Universidade Federal do Paraná; 2010.

12. Pires Neto JAS, Hesse F, Oliveira MAM. Leptospirose equina: aspectos clínicos, tratamento, prevenção e levantamento sorológico. Vet em Foco. 2005; 2:165-76.

13. Secretaria do Estado da Saúde do Paraná/ SESA-PR. Divisão de zoonoses. Banco de dados do sistema de informação de agravos de notificação/SINAN. 2010. Available from: http://dtr2004.saude.gov.br/sinanweb/

14. Stoddard RA, Gee JE, Wilkins PP, McCaustland K, Hoffmaster AR. Detection of pathogenic Leptospira spp. through TaqMan polymerase chain reaction targeting the LipL32 gene. Diagn Microbiol Infect Dis. 2009;64:247-55.

15. World Health Organization. Leptospirosis. [cited 2013 Nov ]. Available from: http://www. who.int/zoonoses/diseases/leptospirosis

16. Yan W, Faisal SM, Divers T, McDonough SP, Akey B, Chang YF. Experimental Leptospira interrogans serovar Kinnewicki infection of horses. J Vet Intern Med. 2010;24:912-7.

Received: 28 January 2013

Accepted: 1 April 2014 